\title{
Prosedur Pelayanan Terhadap Kepuasan Pelanggan Pada Indomaret Tugu Cimanggis
}

\author{
Rita Wahyuni \\ Institut Ilmu Sosial dan Manajemen Stiami \\ Email : rawahyuni@gmail.com
}

\section{ARTICLE INFO}

Keywords

service, customer

\section{ABSTRA C T}

This final report discusses the procedure of service to customer satisfaction at Indomaret Tugu Cimanggis, by doing observation and interview to Indomaret employee and compare it with theory that discuss about service procedure to customer satisfaction. Based on the observations that the author has done this aims to improve service to customer satisfaction Indomaret Tugu Cimanggis. Although there are still many problems encountered, but the problems faced are not too significant so only need a little evaluation to further improve the service to customer satisfaction. The data used are primary data collected and interview to Indomaret Tugu Cimanngis.

\section{PENDAHULUAN}

Sudah sejak lama manusia mengenal dunia bisnis di seluruh penjuru dunia. Banyak sekali jenis bisnis yang kita temui sehari - hari sekaligus juga kita nikmati untuk kepentingan satu sama lain. Salah satu contoh jenis bisnis yang tidak pernah luput dalam keseharian melakukan transaksi adalah bisnis retail atau waralaba. Bisnis retail hampir bisa ditemui di segala bidang, seperti teknologi, kesehatan, properti, makanan dan minuman, otomotif, hiburan, jasa ekspedisi, wisata, penyewaan barang, penyewaan tempat, pakaian, dan masih banyak lagi. Bisnis retail sangat mempunyai hubungan yang erat kepada konsumennya karena antara pelaku bisnis dan konsumen bisa berinteraksi secara langsung.

Konsumen pasti selalu ingin mendapatkan kepuasan pelayanan yang sesuai diharapkan. Maka dari itu perusahaan punya cara untuk mencapai harapan konsumen dengan menawarkan inovasi yang dimiliki. Inovasi perusahaan tersebut juga harus memperhatikan waktu, tempat, biaya, dan tenaga yang bisa digunakan dengan efektif dan efisien oleh para pekerjanya.

Dalam hal ini penulis mencoba untuk membahas tentang prosedur pelayanan terhadap konsumen oleh pelaku bisnis di suatu perusahaan retail yang bergerak dalam bidang makanan dan minuman. Perushaan retail yang penulis maksud adalah INDOMARET

Seiring dengan berkembanganya dunia usaha, banyak perubahan yang terjadi dalam aktivitas usaha untuk meraih sukses bagi setiap perusahaan. Demikian juga halnya dengan persaingan di dunia usaha akan semakin meningkat. Dengan semakin banyaknya produsen yang terlibat dalam pemenuhan kebutuhan dan keinginan pelanggan menyebabkan setiap perusahaan harus menempatkan orientasi pada kepuasan pelanggan sebagai tujuan utama.

Perkembangan retail yang begitu marak dan pesat di kota Jakarta menyebabkan konsumen mempunyai banyak pilihan untuk melakukan pembelian dalam memenuhi kebutuhan dan keinginanya, kondisi tersebut dapat menimbulkan persaingan yang ketat antara retail untuk meraih konsumen dan diperkirakan dapat menyebabkan kesenjangan antara target yang sudah dibuat perusahaan dalam meraih konsumen dengan kenyataan yang terjadi sesungguhnya. Dengan kata lain bidang usaha retail sebagai peluang bisnis yang amat menguntungkan, telah mendorong para pengusaha retail untuk menerapkan strategi pemasaran dan pelayanan yang tepat untuk para pelanggannya. Seperti diketahui bahwa persaingan yang ada diantara para pengusaha retail semakin lama semakin tidak sehat. Hal tersebut juga dapat dilihat dari keberadaan lokasi setiap usaha jenis retail supermarket yang saling berdekatan atau bahkan terkadang bersebelahan satu sama lain. 
Indomaret merupakan salah satu pusat perbelanjaan yang banyak ditemui diberbagai tempat dengan jumlah gerai yang sangat banyak, yang mana mereka sangat memperhatikan faktor harga, lokasi, kelengkapan produk serta kualitas pelayanan bahkan mereka juga melakukan berbagai promosi yang diberikan kepada konsumen mereka. Hal tersebut diberikan dalam rangka menjadikan para konsumennya tersebut terpuasakan dengan pelayanannya. Akan tetapi untuk menumbuhkan loyalitas pelanggan bukanlah hal yang mudah dibentuk, karena penyedia jasa ataupun barang haruslah terlebih dahulu memberikan kepuasan kepada pelanggannya.

Implementasi kualitas pelayanan yang dilakukan oleh suatu perusahaan yang bergerak dibidang jasa atau retail yaitu dengan memberikan kualitas pelayanan (service ) yang terbaik bagi konsumen dengan tujuan untuk menciptakan kepuasan konsumen. Kualitas pelayanan yang diberikan oleh Indomaret akan menimbulkan persepsi konsumen terhadap kualitas yang diberikan. Sering kali terdapat perbedaan antara harapan konsumen dengan persepsi konsumen terhadap kualitas yang diberikan oleh Indomaret. Fenomena yang terdapat pada Indomaret seperti pelayanan yang kurang memuaskan, pelanggan yang ingin dilayani dengan segera, barang yang dijual belum lengkap, dan harga yang tidak sesuai antara yang tertera di rak display dengan harga dikomputer kasir.

Oleh sebab itu Indomaret berusaha untuk dapat memberikan pelayanan yang baik terhadap para pelanggannya, sehingga dapat menciptakan kepuasan dan loyalitas konsumen serta membantu menjaga jarak dengan pesaing, jika Indomaret tidak dapat memenuhi hal tersebut maka akan menimbulkan ketidakpuasan. Untuk mengevaluasi betapa pentingnya kualitas pelayanan pada perusahaan untuk meningkatkan kepuasan pelanggan yang nantinya akan berpengaruh pada PT. Indomarco Prismatama pada lokasi Depok Jawa Barat dengan para pelanggan, maka penulis tertarik untuk mengambil judul "Prosedur Pelayanan Terhadap Kepuasan Pelanggan Pada Indomaret Tugu Tanah baru Depok" yang dapat dijadikan sebagai bahan evaluasi untuk memperbaiki kualitas pelayanan yang sudah ada sebelumnnya.

\section{Landasan teori}

Prosedur

Menurut Sailendra (2015:11) "Prosedur adalah panduan yangdigunakan untuk memastikan kegitan operasional organisasi atau perusahaan agar berjalan dengan lancar."

Menurut Nuraida (2012 : 35) "Prosedur merupakan metode-metode yang dibutuhkan untuk menangani aktivitas-aktivitas yang akan datang, urutan aktivitas untuk mencapai tujuan tertentu, dan pedoman untuk bertindak."

Menurut Mulyadi (2016:4) "Prosedur adalah suatu urutan kegiatan klerikal, biasanya melibatkan beberapa orang dalam satu departemen atau lebih, yang dibuat untuk menjamin penanganan secara seragam transaksi perusahaan yang terjadi secara berulang-ulang"

Menurut Baridwan (2013:30) "Prosedur merupakan suatu urutan-urutan pekerjaan kerani (clerikal), biasanya melibatkan beberapa orang dari suatu bagian atau lebih, disusun untuk menjamin adanya perlakuan yang seragam terhadap transaksi -transaksi perusahaan yang sedang terjadi".

Menurut Machali (2009) : 91) "Prosedur adalah perbuatan atau cara kerja dalam segala tindakan atau proses". Dari semua pengertian tersebut penulis menyimpulkan bahwa "prosedur adalah suatu kegiatan yang tersusun dilakukan oleh dua orang atau lebih, dari satu oraganisasi atau departemen berdasarkan ketentuan atau pedoman yang berlaku dengan tujuan untuk memudahkan dan melancarkan pekerjan"

\section{Pelayanan}

Pelayanan prima merupakan ujung tombak bagi hubungan jangka panjang pelanggan dengan stakeholders-nya, terutama bagi masyarakat. Pelayanan prima erat kaitannya dengan harapan yang muncul di benak pelanggan, sehingga pelayanan perlu diberikan dengan prima sesuai dengan harapan dan kepentingan pelanggan. Melalui pelayanan prima, maka stakeholders pelanggan akan puas, dimana kepuasan tersebut merupakan salah satu kunci bagi suksesnya kinerja pegawai.

Dalam buku Manajemen Pelayanan Prima karangan Donni Juni Priansa tahun (2017:54) yang dikutip dari Elhaitammy dalam Tjiptono (2011) "Pelayanan prima (pelayanan yang unggul) adalah suatu sikap atau cara karyawan dalam melayani pelanggan secara memuaskan. Secara garis besar ada 4 (empat) unsur pokok dalam konsep ini, yaitu kecepatan, ketepatan, keramahan, dan kenyamanan. Komponen yang berjumlah 4 (empat) tersebut merupakan satu kesatuan pelayanan yang terintegrasi, artinya pelayanan atau jasa menjadi tidak excellent bila ada salah satu atau lebih komponen yang kurang. Disamping itu, keempat komponen ini

Rita .... (Prosedur Pelayanan Terhadap Kepuasan Pelanggan Pada Indomaret Tugu Cimanggis) 
akan lebih bermakna bila didukung oleh suatu strategi pelayanan yang tepat, karena strategi pelayanan merupakan arah dan pedoman bagi organisasi untuk memberikan pelayanan terbaiknya".

Dalam buku Manajemen Pelayanan Prima karangan Donni Juni Priansa tahun (2017:54) yang dikutip Yuhanis Abdul Aziz dan Khairil Wahiddin (2010) "Pelayanan prima adalah pelayanan yang melebihi harapan pelanggan. Pelayanan prima tidak digerakan oleh komponen tunggal tetapi membutuhkan konsolidasi dari beberapa komponen untuk membangun entitas keunggulannya. Oleh karena itu, pelayanan prima sangat berkaitan dengan kualitas pelayanan, kepuasan pelanggan, serta mendorong pelanggan untuk melakukan pembelian kembali".

Dalam buku Manajemen Pelayanan Prima karangan Donni Juni Priansa (2017:54) yang dikutip Gronroos dalam Tjiptono (2011) "Pelayanan merupakan proses yang terdiri atas serangkaian aktivitas intangible yang biasa (namun tidak harus selalu) terjadi pada interaksia antara pelanggan dan karyawan, jasa dan sumber daya, fisik atau barang, dan sistem penyedia jasa, yang disediakan sebagai solusi atas masalah pelanggan".

Dalam buku Manajemen Pelayanan Prima karangan Nina Rahmayanti (2010:17) "Pelayanan prima adalah pelayanan yang memenuhi kebutuhan praktis dan kebutuhan emosional pelanggan. Kebutuhan praktis meliputi nilai yang dirasakan dengan berwujud fisik dan kebutuhan emosional yang dirasakan kepada fisiologis pelanggan".

Dalam buku Manajemen Pelayanan Prima karangan Nina Rahmayanti (2010:17) "Pelayanan prima adalah pelayanan yang memilik ciri khas kualitas meliputi kemudahan, kecepatan, ketepatan, kehandalan dan empati dari petugas dalam pemberian dan penyampaian pelayanan kepada pelanggan.

Berdasarkan berbagai pengertian tersebut, dapat disimpulkan bahwa pelayanan prima merupakan pelayanan yang mengutamakan kepentingan pelanggan, baik internal maupun eksternal, sehingga melalui pelayanan tersebut kebutuhan dan keinginan pelanggan dapat terpenuhi secara proposional dan profesional. Pelayanan prima pada dasarnya ditunjukan untuk membangun hubungan jangka panjang yang saling menguntungkan, dimana hubungan tersebut akan menciptakan keterikatan yang kuat.

\section{Ciri - Ciri Pelayanan Prima}

Tujuan pelayanan prima mestinya dipahami dengan baik. Tujuan dari suatu pelayanan pada umumnya adalah dapat memuaskan masyarakat tanpa memandang apapun. Terkait dengan hal tersebut maka sejumlah ciri terkait dengan pelayanan prima adalah sebagai berikut:

a. Efektif

Pelayanan yang diberikan oleh organisasi publik harus efektif, artinya lebih mengutamakan pada pencapaian apa yang telah menjadi tujuan dan sasaran dari organisasi publik.

b. Efisiensi

Pelayanan yang diberikan harus efisien. Yang dimaksud dengan efisien berkenaan dengan: (1) Persyaratan pelanyanan hanya dibatasi pada hal - hal berkaitan langsung dengan pencapaian sasaran pelayanan dengan tetap memperhatikan keterpaduan antara persyaratan dengan produk pelayanan yang berkaitan. (2) Di cegah adanya pengulangan pemenuhan persyaratan, dalam hal proses pelayanan masyarakatyang bersangkutan mempersyaratkan adanya kelengkapan persyaratan dari suatu kerja / intansi pemerintah lain yang terkait. (3) Sederhana, Mengandung arti prosedur maupun tata cara pelayanan diselenggarakan dengan mudah, cepat, tepat, tidak berbelit - belit, mudah dipahami dan mudah dilaksanakan oleh masyarakat yang meminta pelayanan. (4) Kejelasan dan Kepastian Mengandung arti kejelasan dan kepastian mengenai: posedur atau tata cara pelayanan, persyaratan pelayanan, baik persyaratan teknis maupun persyaratan administratif, unit kerja atau pejabat yang berwenang dan bertanggung jawab dalam memberikan pelayanan, rincian biaya atau tarif pelayanan dan tata cara pembayarannya, Jadwal waktu penyelesaian pelayanan. (5) Keterbukaan , mengandung arti prosedur atau tata cara persyaratan, satuan kerja / pejabat penanggung jawab pemberi pelayanan, waktu penyelesaian, rincian waktu / tarif serta hal - hal lain yang berkaitan dengan proses pelayanan wajib diinformasikan secara terbuka agar mudah diketahui dan dipahami oleh masyarakat, baik diminta maupun tidak diminta, (6) Ketepatan Waktu. Kriteria ini mengandung arti pelaksanaan pelayanan masyarakat dapat diselesaikan dalam kurun waktu yang telah ditentukan (7) Responsif Pelayanan yang diberikan bersifat responsif, artinya cepat menanggapi apa yang menjadi masalah, kebutuhan dan aspirasi pelanggan yang dilayani.(8) Adaptif, Pelayanan yang diberikan mampu menyesuaikan dengan tuntutan, keinginan, serta aspirasi pelanggan yang dilayani yang senantiasa bersifat dinamis. 


\section{Jenis - Jenis Pelayanan Prima}

Pelayanan prima dapat ditampilkan dalam banyak jenis. Berikut ini disajikan beberapa jenis pelayanan prima pada umumnya dikenal, yaitu:

a. Pelayanan Prima Melalui Lisan

Pelayanan prima melalui lisan pada umumnya dilakukan oleh pegawai front liner organisasi publik yang pada umumnya mereka bersentuhan langsung dengan pelanggan eksternal. Namun demikian, pelayanan prima secara internal pun dapat dilakukan dengan membiasakan pegawai untuk berkata - kata yang positif, inspiratif, dan saling memotivasi.

b. Pelayanan Prima Melalui Tulisan

Pelayanan prima melalui tulisan merupakan salah satu bentuk pelayanan yang paling menonjol dalam kegiatan operasional pelayanan. Sistem pelayanan melalui tulisan didominasi oleh sistem komputerisasi yang dikolaborasikan dengan internet.

c. Pelayanan Prima Melalui Perbuatan

Pelayanan dalam bentuk perbuatan dilakukan oleh pegawai - pegawai yang memiliki kompetensi teknis di level kegiatan operasional pelayanan. Pelayanan ini mengkolaborasikan pelayanan melalui lisan dan tulisan.

\section{Budaya Pelayanan Prima}

Tantangan terpenting dalam menciptakan pelayanan prima adalah bagaimana menciptakan budaya pelayanan prima, dimana budaya tersebut perlu menjadi ruh bagi kegiatan pelayanan. Untuk menciptakan budaya pelayanan prima, maka pola hubungan perlu dibangun dengan model hubungan yang saling tolong menolong (helping relationship). Model hubungan dinamis tersebut bergantung pada keterampilan menolong (helping skill) dari sumberdaya manusia yang ada. Keterampilan menolong dibentuk atas dasar prinsip altruisme, yakni kecenderungan bertingkah laku menolong orang lain secara sukarela, tanpa harapan mendapatkan imbalan, melainkan perasaan bermakna karena telah melakukan sesuatu yang baik.

\section{Jenis - Jenis Budaya Pelayanan}

Sethia dan Glinow (Collins dan Mc Laughin, 1996) menyatakan empat jenis budaya organisasi apabila kita menganalisis budaya dari dua aspek, yaitu bagaimana hubngan antar pegawai dan perhatian pegawai terhadap pelaksanaan tugas - tugas pelayanan. Keempat jenis budaya tersebut yaitu:

a. $\quad$ Budaya Apatis (Apathetic Culture)

Budaya apatis adalah budaya kekuasaan dan permainan politik antar pimpinan dan pegawai yang sangat kental. Kinerja ini sangat rendah karena semua pegawai melaksanakan tugas hanya jika mereka diperintah oleh pimpinan. Selain itu, sikap pegawai lebih mementingkan perintah pimpinan daripada inisiatif pribadi untuk memberikan pelayanan bagi pelanggan, karena mereka beranggapan bahwa pimpinan terkait dengan karir mereka secara langsung.

b. Budaya Peduli (Caring Culture)

Budaya peduli dicirikan dengan rendahnya perhatian pegawai terhadap pelaksanaan tugas, tetapi sangat tinggi terhadap hubungan yang harmonis sesama pegawai. Penghargaan terhadap pegawai lebih diutamakan dimana hubungan dibangun secara harmonis, serasi, dan penuh suasana kekeluargaan. Dengan kata lain, budaya tipe ini meletakan kebersamaan dan keharmonisan pegawai lebih tinggi dibandingan dengan kinerja pelayanan.

c. Budaya Kompetisi (Exacting Culture)

Ciri utama budaya kompetisi adalah bahwa pegawai lebih mementingkan kinerja organisasi dibandingkan dengan hubungan antar pegawai. Oleh karena itu, keharmonisan antar pegawai sangat rendah, dimana setiap pegawai berupaya untuk berkompetisi menjadi yang terbaik sehingga hubungan yang terbangun menjadi tidak harmonis, serasi, dan penuh kekeluargaan.

c. Budaya Integratif (Integrative Culture)

Budaya tipe ini dicirikan oleh sikap para pegawai yang mementingkan hubungan antar pegawai yang baik dan perhatian yang tinggi terhadap kinerja pelayanan. Budaya ini adalah budaya yang ideal dimana hubungan sosial antar pegawai dan kinerja yang dihasilkan pegawai bagi toko sama - sama tinggi. 
Pelayanan yang Baik (Berkualitas)

Pengertian pelayanan yang baik adalah kemampuan perusahaan memberikan pelayanan yang dapat memberikan kepuasan kepada pelanggan sesuai dengan kebutuhan dan keinginannya. Artinya pelanggan akan merasa puas dan terus menambah transaksi atau konsumsinya dari waktu ke waktu. Terdaoat beberapa faktor yang berpengaruh langsung terhadap mutu pelayanan yang diberikan. Pertama,pelanyanan yang baik dipengaruhi oleh faktor manusia (karyawan) yang memberikan pelayanan tersebut. Kemudian kedua, pelayanan yang baik juga harus diikuti oleh tersedianya sarana dan prasarana yang mendukung kecepatan, ketepatan, dan keakuratan pekerjaan.

Berikut ini beberapa ciri pelayanan yang baik yang harus diikuti oleh manajemen dalam melayani pelanggan yaitu :

a. Tersedia karyawan yang baik

b. Tersedia sarana dan prasarana yang baik

c. Bertanggung jawab kepada setiap pelanggan sejak awal hingga selesai

d. Mampu melayani secara cepat dan tepat

e. Mampu berkomunikasi

f. Memberikan jaminan kerahasiaan setiap transaksi

g. Memiliki pengetahuan dan kemampuan yang baik

h. Berusaha memahami kebutuhan pelanggan

i. Mampu memberikan kepercayaan kepada pelanggan

Manfaat Pelayanan

Menurut Blumberg (1999:10) manfaat pelayanan yaitu :

a. Pelayanan memperpanjang dasar hidup suatu produk yaitu pelayanan bukan saja bagian yang penting dari suatu produk, tapi juga memberikan pendapatan dan keuntungan yang lebih besar melalui dasar hidup suatu produk.

b. Pelayanan dapat menambah nilai suatu produk secara langsung. Untuk produk-produk yang memerlukan pelayanan sebagai unsur tambahan seperti penghantaran, pemasaran, dan garansi, konsumen bersedia menambah bayaran itu asalkan dapat menambah nilai suatu produk.

Untuk itu perusahaan harus mengutamakan kualitas pelayanan, sebab kualitas pelayanan dapat menumbuhkan minat konsumen untuk kembali lagi. Pelanggan yang puas juga cenderung akan memberikan referensi yang baik terhadap pelayanan kepada orang lain.

\section{Konsep dasar Pelanggan}

Pelanggan adalah semua orang yang menuntut perusahaan untuk memenuhi suatu standar tertentu kualitas tertentu, dan karena itu akan memberikan pengaruh pada performansi perusahaan L.L. Bean, freeport Maine ( dalam Nasution, 2010:46),memberikan beberapa definisi tentang pelanggan yaitu :

a. pelanggan adalah orang yang tidak tergantung pada kita, tetapi kita yang tergantung padanya.

b. Pelanggan adalah orang yang membawa kita kepada apa keinginannya

c. Tidak ada seorangpun yang pernah menang beradu argumentasi dengan pelanggan

d. Pelanggan adalah orang yang teraman penting yang harus dipuaskan

Philip kotler dalam bukunya manajemen pemasaran analisis perencanaan, implementasi dan kontrol (2002: 24) berpendapat : Pembeli / pelanggan adalah orang yang paling diharapkan kedatangannya dalam suatu perusahaan.

Jadi pelanggan adalah raja dan kita harus bisa melayaninya dengan baik, apa saja yang kita miliki, mereka akan membayarnya jika sesuai kebutuhannya. Karena tanpa pelanggan maka bisnis kita jalani tidak akan bertahan lama. Yang diinginkan oleh pelanggan adalah :

a. Pelanggan dibuat bahagia dan puas

b. Pelanggan ingin kebutuhannya terpenuhindan sesuai dengan harapannya

c. Pelanggan tidak ingin dibebankan macam macam dalam bentuk uang atau waktu 


\section{Pengertian Sifat-sifat Pelanggan}

Karyawan perlu mempelajari kebiasaan pelanggan, terutama bagi mereka yang sudah berkali-kali datang. Hal ini disebabkan masing-masing pelanggan memilliki sifat-sifat yang berbeda. Perbedaan sifat-sifat pelanggan disebabkan karena daerah, asal-usul, suku, agama, pendidikan, pengalaman, adat istiadat, perilaku, selera, dan budayanya.

Menurut Dr. Kasmir, S.E., M.M. (2017:46) "sifat-sifat pelanggan merupakan ciri khas dari perilaku yang dimiliki oleh pelanggan"

Sifat-sifat Pelanggan

Berikut ini sifat-sifat pelanggan yang harus dikenal agar mampu memberikan pelayanan yang baik yaitu:

a. Pelanggan dianggap sebagai raja

Pelanggan ingin dianggap sebagai raja artinya semua keinginan dan kebutuhannya harus dilayani secara sempurna.

b. Mau dipenuhi keinginan dan kebutuhannya

Keinginan dan kebutuhan pelanggan mulai dari hanya ingin memperoleh informasi tentang satu hal (produk) yang belum diketahui oleh pelanggan, atau ada informasi yang kurang jelas, sehingga pelanggan perlu tahu, misalnya informasi tentang isi, manfaat atau harga produk tersebut.

c. Pelanggan tidak mau didebat dan tidak mau disinggung

Sifat-sifat kebanyakan pelanggan atau nasabah yaitu mereka paling tidak suka dibantah keinginan atau pendapatnya. Pelanggan juga tidak suka didebat artinya dalam hal ini karyawan dalam menyampaikan informasi atau pendapat apabila mendapat respons yang kurang baik dari pelanggan, perlu menyikapinya secara hati-hati, agar pelanggan merasa tidak dibantah atau didebat.

d. Pelanggan atau nasabah mau diperhatikan

Pelanggan yang datang ke perusahaan pada hakikatnya ingin memperoleh perhatian. Jangan sekali-kali menyepelekan atau membiarkan pelanggan, berikan perhatian secara penuh sehingga pelanggan benarbenar merasa diperhatikan.

e. Pelanggan atau nasabah ingin selalu dipuji

Pelanggan atau nasabah pada hakikatnya paling senang dipuji atau disanjung oleh siapa pun, termasuk oleh karyawan. Namun perlu diingat hendaknya pujian kepada pelanggan dilakuka secara wajar dan pada waktu yang tepat.

f. Pelanggan atau nasabah merupakan sumber pendapatan perusahaan

Karyawan selalu menganggap bahwa setiap pelanggan yang datang merupakan sumber pendapatan perusahaan. Dengan demikian karyawan harus termotivasi untuk melayani pelanggan dengan sebaikbaiknya.

Cara Mengenal Perilaku Pelanggan

Pada dasarnya pelanggan dibagi 3 (tiga) golongan, yaitu:

a. Pelanggan baru pertama kali

Artinya pelanggan yang belum pernah datang sebelumnya dan ini kali pertama pelanggan datang ke perusahaan.

b. Pelanggan yang sudah bertransaksi lebih dari sekali. Biasanya pelanggan yang sudah pernah datang dan merasa terkesan dengan layanan yang diberikan.

c. Pelanggan lama dan setia.

Artinya pelanggan yang sudah sering datang ke perusahaan bahkan sudah menjadi langganan perusahaan sejak lama. Pelanggan seperti ini biasanya tetap melakukan transaksi di perusahaan kita, sekalipun di tempat lain juga tersedia.

Mengenal Karakter pelanggan

Keterampilan dasar yang dibutuhkan untuk mengenal karakter pelanggan :

a. Pusatkan perhatian pada pelanggan

b. Memberikan pelayanan yang efesien

c. Meningkatkan harga diri pelanggan 
d. Membina hubungan baik dengan pelanggan

e. Dapat menentukan apa keinginan pelanggan

f. Mengalihkan pelayanan kepada orang lain

Definisi Harapan pelanggan

Menurut Olso dan Dover ( dalam Zeuthaml et al.1993 ) harapan pelanggan merupakan keyakinan pelanggan sebelum mencoba atau membeli produk, yang dijadikan standar atau acuan dalam menilai kinerja produk tersebut.

Kepuasan pelanggan sangat tergantung dari persepsi dan ekspestasi mereka. Oleh karena itu, gasperz ( 1997 dalam nasution 2010 : 50) menyebutkan faktor faktor yang mempengaruhi persepsi dan harapan pelanggan sebagai berikut :

a. Kebutuhan dan keinginan yang berkaitan dengan hal hal yang dirasakan pelanggan ketika ia sedang mencoba melakukan transaksi dengan produsen / pemasok produk (perusahaan).

b. Pengalaman masa lalu ketika mengkonsumsi produk dari perusahaan maupun pesaing pesainnya

c. Pengalaman dari teman teman, dimana mereka akan menceritakan kualitas produk yang akan dibeli oleh pelanggan

d. Komunikasi melalui iklan dan pemasaran juga mempengaruhi persepsi pelanggan.

Harapan Pelanggan

Ada 4 harapan Pelanggan :

a. Kegunaan, yaitu kebutuhan dan manfaat produk barang dan jasa

b. Kinerja, yaitu seberapa besar produk dan jasa dapat memenuhi kegunaan produl itu sendiri

c. Harga, yaitu besarnya uang dan pengorbanan yang harus dibayar konsumen untuk produk tersebut

d. Penyajian produk barang dan jasa

\section{Metode Penelitian}

Pendekatan dalam penelitian ini adalah penelitian kualitatif. Penelitian ini berusaha mendeskripsikan Prosedur Pelayanan Terhadap Kepuasan Pelanggan Pada Indomaret Tugu Cimanggis

Selain itu dalam penelitian ini peneliti sebagai instrumen utama karena peneliti yang merencanakan, melaksanakan, mengumpulkan data, menganalisis data, menarik kesimpulan, dan membuat laporan. Oleh karena itu pendekatan yang digunakan dalam penelitian ini adalah pendekatan kualitatif. Pengumpulan data dilakukan melalui observasi dan wawancara.

\section{Pembahasan}

Dalam melayani pelanggan pegawai indomaret selalu memakai seragam indomaret berwarna biru. Jam kerja di indomaret menggunakan 2 Shift, shift pertama jam 007 sd jam 15.00 dilanjutkan shift ke 2 yaitu jam 14.00 sd jam 22.00 malam. Jumlah pegawai pada indomaret tugu Cimanngis berjumlah 6 orang.pegawai. Pada indomaret apabila mau mengajukan izin untuk tidak masuk harus mengajukan 1 bulan sebelumnya baru akan disetujui. Dan pegawai di indomaret juga akan mendapatkan uang lembur apabila masuk di tanggal merah atau bisa menggantikan temannya yang tidak bisa hadir.

\section{Prosedur Pelayanan di Indomaret}

Pelayanan yang dilakukan di Indomaret adalah pelayanan dengan mengutamakan kepuasan pelanggan karena tujuan utama dalam bidang usaha, tanpa pelanggan usaha tidak akan berjalan. Dengan pelayanan yang baik pelanggan akan tertarik dan merasa puas datang berbelanja di Indomaret. Pelanggan akan tertarik dengan promosi / penawaran yang ada dan harga yang kompetitif. 


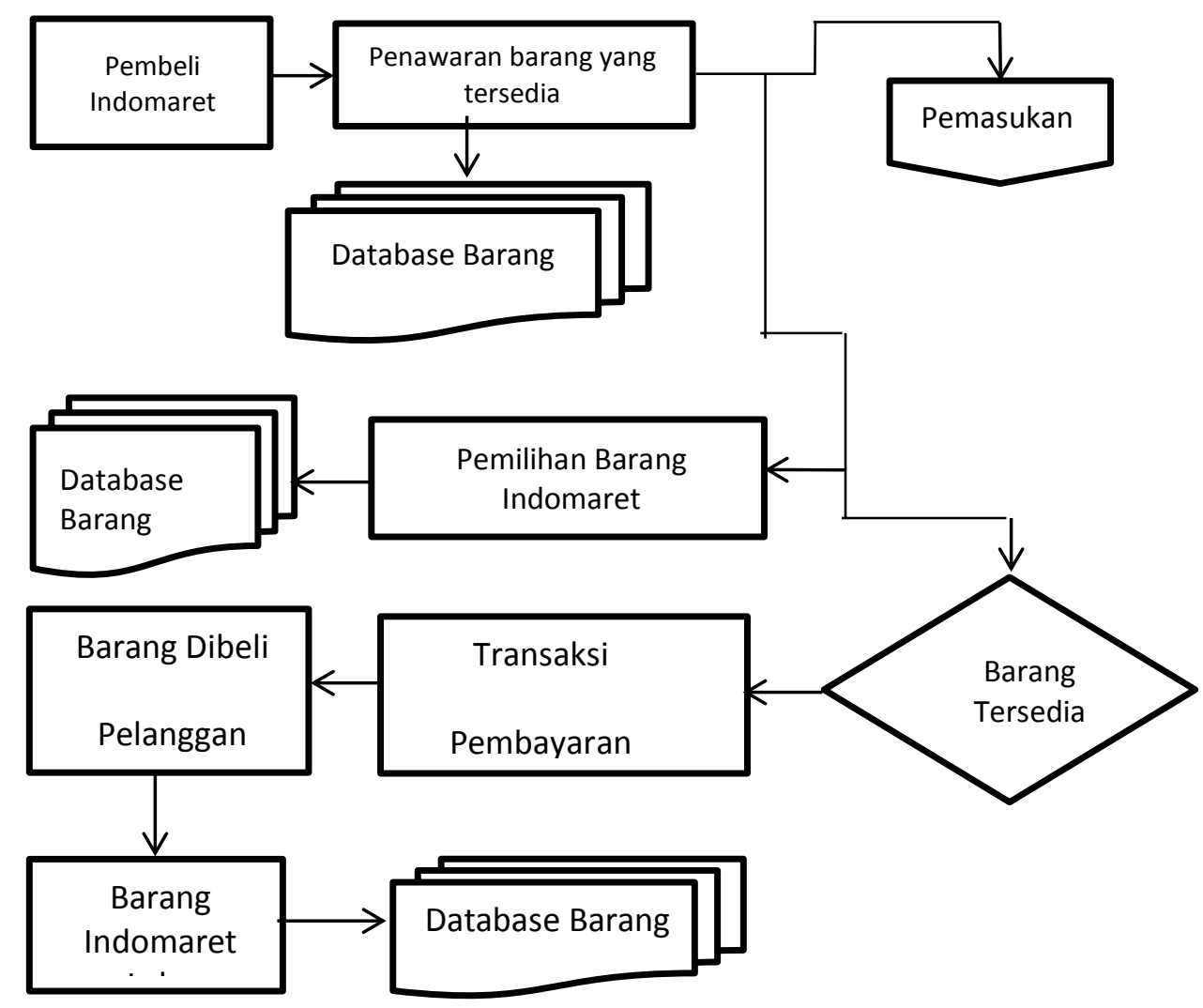

Gambar 1. Prosedur Pelayanan Pelanggan Indomart Tugu Cimanggis

a. Pelanggan datang ke Indomart Tugu Cimanggis

b. etika pelanggan datang pelayan memberi senyuman dan salam sapa untuk pelanggan.

c. Pelayan menanyakan ada yang bisa dibantu pada saat pelanggan kebingungan mencari barang yang akan dibeli.

d. Apabila ada barang barang promo diberitahukan kepada pelanggan yang tidak tau tentang promo yang ada di indomart

e. Setelah menunjukan tempat barang yang dicari oleh pelanggan maka pelayan mengarahkan ke meja kasir.

f. Setelah di meja kasir pelayan menanyakan apakah ada lagi yang mau ditambahkan belanjaannya ke pada pelanggan.

g. Mengecek kembali total item barang dan menghitung harga barang yang dibeli oleh pelanggan pada mesin kasir.

h. Pelayan menerima pembayaran dan menghitung kembalian untuk pelanggan.

\section{Kendala Yang Dihadapi}

Dalam meningkatkan kinerja pelayanan terhadap pelanggan Indomaret ditemukan beberapa faktor kendala, faktor - faktor tersebut antara lain :

a. Prosedur pelaksanaan pelayanan Indomaret

Pelayanan yang memuaskan atau pelayanan prima akan membuat pelanggan bertahan dan tidak kabur ke pesaing produk sejenis lainnya, perusahaan wajib melayani pelanggan dengan baik agar merasa puas jangan pilih kasih atau membeda bedakan pelangan agar pelanggan menjadi pelanggan tetap / pelanggan setia.

b. Kendala yang ada dalam pelayanan terhadap kepuasan pelanggan pada Indomaret seperti : 
1) Harga yang tidak sesuai / berbeda

Harga yang di rak display dengan di komputer kasir berbeda, sehingga membuat banyak komplain dari pelanggan. Contohnya harga 2 liter minyak goreng di rak display Rp 22.000,- tetapi di komputer Rp 24.000,-

2) Barang yang dijual belum lengkap

Stok barang yang ada di Indomaret belum semuanya ada sehingga pelanggan yang datang bertanya tetapi tidak ada barangnya akan segera meninggalkan toko dan kemungkinan tidak akan kembali dan berpindah ketempat lain karena pelanggan merasa toko Indomaret tidak lengkap.

3) Terjadinya komplain

Sering terjadinya komplain dari pelanggan dikarenakan pegawai salah pengimputan item pada saat pelanggan berbelanja.

4) Masih banyak pelanggan yang belanja karena harga promosi, dan pada saat barang/stock promosi sudah habis atau sedang tidak ada pelanngan tidak jadi belanja

\section{Solusi Dari Kendala Yang Dihadapi}

a. Agar pelanggan tidak kecewa sebaiknya sebelum barang dijual atau di iklankan secara promo. Harga harus selalu di update, sebagai salah satu minimarket terbesar di indonesia sudah seharusnya pihak manajemen selalu mengupdate barang yang tersedia dan selalu mengupdate harga terbaru setiap hari dari harga barang yang di jual/ barang yang di promo

b. Stock barang yang belum tersedia, jika ada pelanggan yang mencari produk tertentu dan tidak ada seharusnya karyawan yang melayani bisa melakukan komunikasi ke pelanggan dan mencarikan barang yang sama tapi berbeda merk, dan untuk pihak manajemen bisa menjadikan sebuah masukan dari pelanggan yang mencari barang tidak ada atau tidak tersedia agar melakukan penambahan - penambahan item barang yang belum tersedia. atau yang sering dicari oleh pelanggan.

c. Kesalahan dalam menginput barang belanjaan akan mengecewakan pelanggan, untuk menghidari kesalahan tersebut sebelum di enter sebaiknya diperiksa lagi ada berapa macam barang yang dibeli jangan sampai double menginput atau salah menginput harga. Dan kepada pelanggan seharusnya lebih teliti dan lebih berhati - hati pada saat bertransaksi agar tidak terjadi salah penginputan barang, sebelum pergi meninggalkan tempat sebaiknnya diperiksa kembali struk pembeliannya

d. Harga barang promo sebaiknya tetap diadakan oleh pihak Indomart tidak harus setiap hari tapi biasanya barang promo dijual pada hari sabtu dan minggu, agar tidak membuat pelanggan kabur tetap harapannya bisa dikabulkan oleh pihak indomart

\section{KESIMPULAN}

Prosedur pelaksanaan pelayanan Indomaret Tugu Cimanggis Depok, masih belum optimal penerapannya, hal ini dapat disimpulkan sebagai berikut:

1. Pelanggan datang ke Indomaret Tanah baru Depok, ketika pelanggan datang pelayan memberi senyuman dan salam sapa untuk pelanggan, pelayan menanyakan ada yang bisa dibantu pada saat pelanggan kebingungan mencari barang yang akan dibeli, apabila ada barang barang promo diberitahukan kepada pelanggan yang tidak tau tentang promo yang ada di Indomart, setelah menunjukan tempat barang yang dicari oleh pelanggan maka pelayan mengarahkan ke meja kasir, setelah di meja kasir pelayan menanyakan apakah ada lagi yang mau ditambahkan belanjaannya ke pada pelanggan, mengecek kembali total item barang dan menghitung harga barang yang dibeli oleh pelanggan pada mesin kasir, pelayan menerima pembayaran dan menghitung kembalian untuk pelanggan.

2. kendala - kendala yang dihadapi oleh indomaret meliputi :

a. Harga barang yang tidak sesuai / berbeda yang ada di rak/display dengan yang di mesin hitung

b. Barang yang dijual belum lengkap ( yang dicari pelanggan kadang tidak ada)

c. Sering terjadinya komplain (dalam menginput barang barang belanjaan kadang salah).

d. Pelanggan kadang hanya mencari barang barang promo pada saat barang tersebut sudah tidak ada pelanggan tidak jadi belanja

3. Penulis berusaha memberikan solusi untuk mengatasi kendala yang ada sesuai teori yang ada dalam pembahasan seperti : 
a. Untuk mengatasi masalah harga yang tidak sesuai sering terjadi karena human error seperti kasir lupa untuk mengupdate harga barang, maka sebaiknya kasir selaku penanggung jawab harus menjadwalkan setiap ada barang datang atau barang promo untuk diberikan harga/label sebelum barang barang dijual.

b. Masalah ketidaktersedian barang yang dicari pelanggan terjadi karena pihak Indomaret belum melakukan perluasan kepada perusahaan / suplier, maka sebaiknyan idomaret bisa menambah kerjasama dengan suplayer suplayer lain untuk mensuplay barang barang yang belum ada di indomaret.

c. Agar tidak terjadi kesalahan dalam menginput barang belanjaan,sebaiknya kasir menghitung kembali barang yang dibeli dengan struknya dan bagi pelanggan juga ikut memeriksa sebelum meninggalkan tempat.

d. Bagi pelanggan yang mencari barang promo, ternyata barang promonya tidak ada sebelum pelanggan meninggalkan indomart sebaiknya pegawai indomart bisa menawarkan barang barang promo lainnya kepada pelanggan.

\section{DAFTAR PUSTAKA}

Undang-undang nomor 8 tahun 1999 tentang Perlindungan Konsumen pasal 3 huruf f.

Undang-undang nomor 8 tahun 1999 tentang Perlindungan Konsumen pasal 4 huruf a.

Barata, Atep Adya. (2014). Dasar - Dasar Pelayanan Prima. Cetakan Pertama-Jakarta: PT. Elex Media Komputindo.

Priansa, Donni Juni.(2017). Manajemen Pelayanan Prima. Cetakan Pertama-Bandung: Alfabeta

Rahmayanty, Nina. (2010). Manajemen Pelayanan Prima. Jakarta:Graha Ilmu

Sudaryono. (2016). Manajemen Pemasaran teori \& Implementasi. Yogyakarta:Andi

Solikin, M. (2011). Pelayanan Prima. Jakarta: Inti Prima Promosindo

https://indomaret.co.id/korporat/seputar-indomaret/peduli-dan-berbagi/2014/01/16/sejarah-dan-visi/ 